Bài báo khoa học

\title{
Chất lượng nước sông Cái Nha trang trước và sau khi có đập ngăn mặn
}

\author{
Huỳnh Phú ${ }^{*}$, Nguyễn Lý Ngọc Thảo1, Đặng Văn Đông², Vũ Hũu Dụng ${ }^{3}$ \\ ${ }^{1}$ Trường Đại học công nghệ TP Hồ Chí Minh, (HUTECH); h.phu@ hutech.edu.vn; \\ nln.thao@hutech.edu.vn \\ ${ }^{2}$ Công ty TNHH TM DV Đông Vinh; sales@ dovitech.com.vn \\ ${ }^{3}$ Hoc viên Cao học; vuhuudung93@gmail.com \\ *Tác giả liên hệ: h.phu@hutech.edu.vn; Tel.: +84-9666 87548 \\ Ban Biên tập nhận bài: 08/4/2021; Ngày phản biện xong: 23/6/2021; Ngày đăng bài: \\ $25 / 8 / 2021$
}

Tóm tắt: Sông Cái Nha Trang là một trong ba con sông lớn của tỉnh Khánh Hòa, sông này đóng một vai trò rất quan trọng trong việc cung cấp nguồn nước ngọt phục vụ cho dân sinh, phát triển kinh tế-xã hội. Nghiên cứu, sử dụng mô hình MIKE với mô-đun MIKE NAM để tính toán dòng chảy do mưa, làm điều kiện đầu vào cho mô-đun MIKE 11, mô phỏng thủy lực xâm nhập mặn và chất lượng nước tập trung chính thành phố Nha trang, thị xã Ninh hòa, thị trấn Diên khánh... Khi chưa có đập, ở thượng lưu các thông số như BOD BO $_{5}: 8,5 \mathrm{mg} / \mathrm{l}$, tổng $\mathrm{N} 1,62-5,22 \mathrm{mg} / \mathrm{l}$, các thông số này cũng tăng dần theo thời gian trong mùa kiệt. Độ mặn khi triều cao lên đến $31,55 \%$. Khi đập được xây dựng $\mathrm{BOD}_{5}$ giảm từ $8,5 \mathrm{mg} / \mathrm{l}$ xuống $4,13 \mathrm{mg} / \mathrm{l}$, độ mặn < 4\%o. Bài báo trình bày các kết quả ứng dụng bộ mô hình Mike 11 mô phỏng diễn biến chất lượng nước sông Cái Nha Trang trước và sau khi có đập ngăn mặn.

Từ khóa: Chất lượng nước; Đập ngăn mặn; Xâm nhập mặn; Sông Cái Nha Trang.

\section{Mở đầu}

Sông cái Nha trang trước đây có tên là sông Cù hay sông Phú Lộc và ở phần thượng lưu có tên gọi là sông Thác Ngựa, dài $79 \mathrm{~km}$. Sông bắt nguồn từ dãy núi cao ở phía Tây có cao độ từ 1.500-2.000 m, chảy theo hướng Tây-Đông và đổ ra biển ở cửa Hà Ra và Xóm Bóng ngay TP. Nha Trang. Lưu vực sông Cái Nha Trang bao gồm toàn bộ 2 huyện Khánh Vĩnh và Diên Khánh, thành phố Nha Trang và một phần huyện Cam Lâm. Sông Cái Nha Trang có 5 phụ lưu chính tập trung nước vào dòng chính [1-2].

Do các phụ lưu chảy qua các khu vực mưa khác nhau, trong đó có nhiều tâm mưa lớn (như tâm mưa Hòn Bà với lượng mưa nam 2.500-3.000 mm) nên dòng chảy sông Cái Nha Trang khá dồi dào, tập trung vào các tháng 10 và 11 đạt $695 \mathrm{~m} / \mathrm{s}$, lưu lượng nhỏ nhất vào tháng 4 chỉ có $4,3 \mathrm{~m}^{3} / \mathrm{s}$ [3-5]. Vào mùa lũ nước sông bị đục do vật chất hữu cơ và bùn cát, phù sa từ thượng nguồn đổ về, vào mùa khô nước trở nên trong hơn, nhưng phía hạ lưu nguồn bị xâm nhập mặn, thông thường biên mặn khoảng $3 \mathrm{~km}$ kể từ của Xóm Bóng [6].

Nghiên cứu chất lượng nước sông Cái Nha trang trước và sau khi có đập ngăn mặn, tác giả ứng dụng bộ phần mềm MIKE 11-Ecolab. Các mô hình tính toán, mô phỏng, đánh giá chất lượng môi trường nước rất phổ biến trên thế giới. Mô hình WASP7 (Water Quality Analysis Simulation Program 7) [7-8]. Mô hình WASP cũng có thể liên kết với các mô hình thủy động lực. Mô hình QUAL2K (hay Q2K) (River and Stream Water Quality Model) được nâng cấp từ mô hình trước đó là QUAL2E. Mô hình DELFT 3D của Viện nghiên cứu thuỷ lực Hà Lan kết hợp mô hình thuỷ lực 3 chiều với mô hình chất lượng nước. ECOHAM mô 
hình số $3 \mathrm{D}$ kết hợp module thủy lực với module sinh thái của Trường đại học Hamburg (Đức). ECOSMO (ECOSystem MOdel) là mô hình cặp ba chiều thủy động lực-băng biển-sinh địa hóa. Bộ phần mềm MIKE do Viện Thuỷ lực Đan Mạch (DHI) tích hợp các module thuỷ lực $(\mathrm{HD})$ và chất lượng nước (ECO Lab).

Ở Việt nam, tại Nha trang đã sử dụng kết hợp mô hình một chiều (1D) và mô hình vật lý (3D) nghiên cứu tác động của các công trình xây dựng trên sông cải thiện tình hình dòng chảy và diễn biến sông sau khi xây dựng các công trình kè và đường [9-11], sử dụng bộ mô hình MIKE tính toán cho toàn lưu vực sông Cái; Tại Vịnh Cam Ranh đề tài sử dụng mô hình ECOSMO để tính toán, mô phỏng lan truyền một số thành phần vật chất gây ô nhiễm. Nghiên cứu [12] do Trung tâm nghiên cứu Môi trường và $B Đ K H$ (Viện Kỹ thuật Biển) thực hiện năm 2011 [13]. Kết quả các nghiên cứu là cơ sở dữ liệu tổng hợp về tài nguyên nước, là những kinh nghiệm quý, phương pháp luận rất tốt.

Nghiên cứu xác định được sự thay đổi chất lượng nước trước và sau khi có đập ngăn mặn làm cơ sở đề xuất các biện pháp giảm thiểu ô nhiễm và bảo vệ chất lượng nước sông Cái Nha Trang...Ứng dụng thành công mô hình MIKE 11, MIKE Ecolab mô phỏng diễn biến chất lượng nước sông Cái Nha Trang theo các kịch bản khai thác nguồn nước.

\section{Phương pháp nghiên cứu và tài liệu tính toán}

\subsection{Vị trí và phạm vi nghiên cứu}

Phạm vi nghiên cứu được tính từ ngã ba cửa sông Chò đổ vào sông Cái Nha Trang (SCNT), thượng lưu Trạm Thủy văn Đồng Trăng thuộc địa phận huyện Diên Khánh tới cầu Trần Phú thuộc địa phận Tp. Nha Trang, tỉnh Khánh Hòa với chiều dài khoảng 16 km.

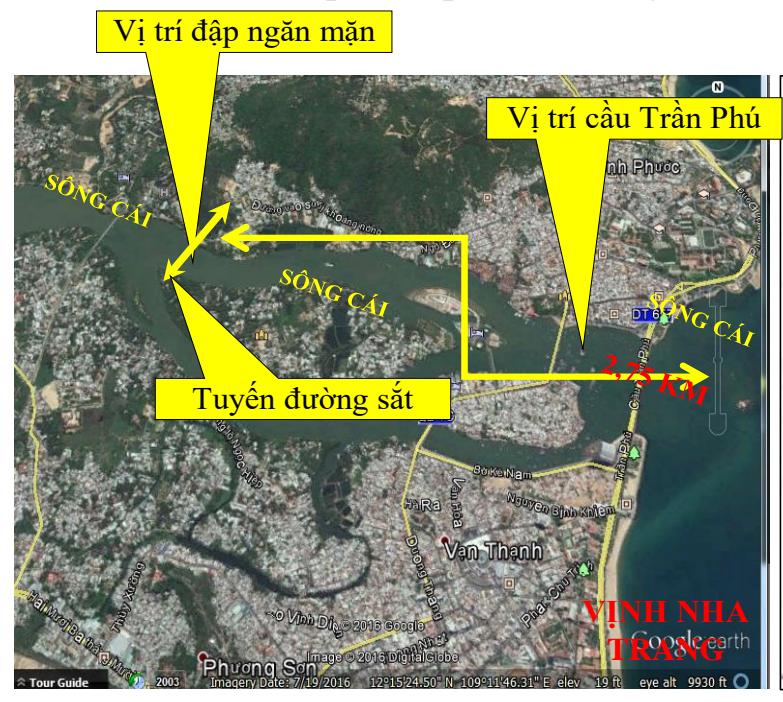

(a)

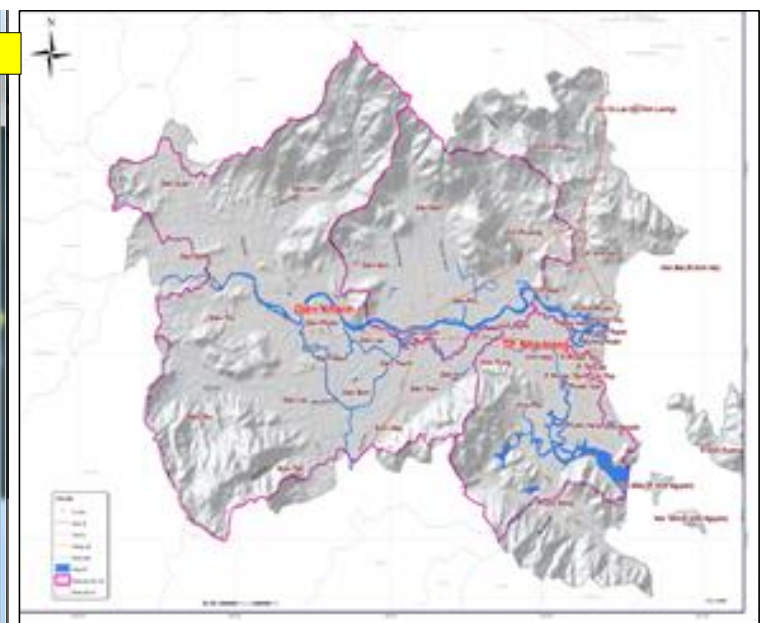

(b)

Hình 1. Sơ đồ vị trí đập ngăn mặn trên lưu vực sông Cái Nha Trang: (a) Sơ đồ vị trí đập ngăn mặn Sông Cái; (b) Lưu vực sông Cái Nha Trang.

Sông Cái Nha Trang là con sông lớn nhất ở Khánh Hòa có vị trí địa lý trong khoảng $12^{\circ} 03^{\prime}-12^{\circ} 37^{\prime}$ vĩ độ Bắc, $108^{\circ} 41^{\prime}-109^{\circ} 12^{\prime}$ kinh độ Đông, với diện tích lưu vực vào khoảng $2.000 \mathrm{~km}^{2}$. Trên lưu vực sông Cái Nha Trang, nhiều khu công nghiệp, trang trại và khu dân cư, hàng ngày phải tiếp nhận lượng nước thải chưa qua xử lý không kiểm soát. Vào mùa khô nước biển xâm nhập sâu vào đất liền làm cho nguồn nước bị xâm nhập mặn. Nhằm kiểm soát được chất lượng nước sông Cái, dự án xây dựng đập ngăn mặn trên sông Cái Nha Trang được hình thành. Vị trí lấy mẫu nằm phía hạ lưu và cách cầu đường sắt khoảng $75 \mathrm{~m}$ thuộc địa phận xã Vĩnh Ngọc, Thành Phố Nha Trang, tỉnh Khánh Hòa. Vị trí này sông thẳng, rộng khoảng 180-200 $\mathrm{m}$ và mở rộng dần về phía biển, cao độ đáy sông khoảng $-5,0 \mathrm{~m}$ đến $-6,0 \mathrm{~m}$ [3-5]. 


\subsection{Phưong pháp nghiên cứu}

- Phương pháp điều tra khảo sát thực địa: điều tra, khảo sát và thu thập các thông tin về điều kiện tự nhiên, khí tượng thủy văn, lấy mẫu nước phục vụ cho tính toán biến đổi ô nhiễm.

- Phương pháp thống kê: Thu thập và xử lý các số liệu về khí tượng thủy văn như lượng mưa, lưu lượng, mực nước và số liệu về các chất ô nhiễm.

- Phương pháp so sánh. Kết quả phân tích được so sánh với QCVN 08: 2011/BTNMT

- Phương pháp mô hình toán: Ứng dụng mô hình MIKE 11 vào nghiên cứu biến đổi chất ô nhiễm trên lưu vực sông Cái Nha trang.

Đây là một công cụ mô hình một chiều rất có ích với người sử dụng trong việc thiết kế chi tiết, quản lý và điều hành các hệ thống sông và kênh từ đơn giản tới phức tạp. Bộ mô hình MIKE 11: Mô đun River Network Editor cho phép người sử dụng tạo, chỉnh sửa và quan sát các dữ liệu hệ thống sông.
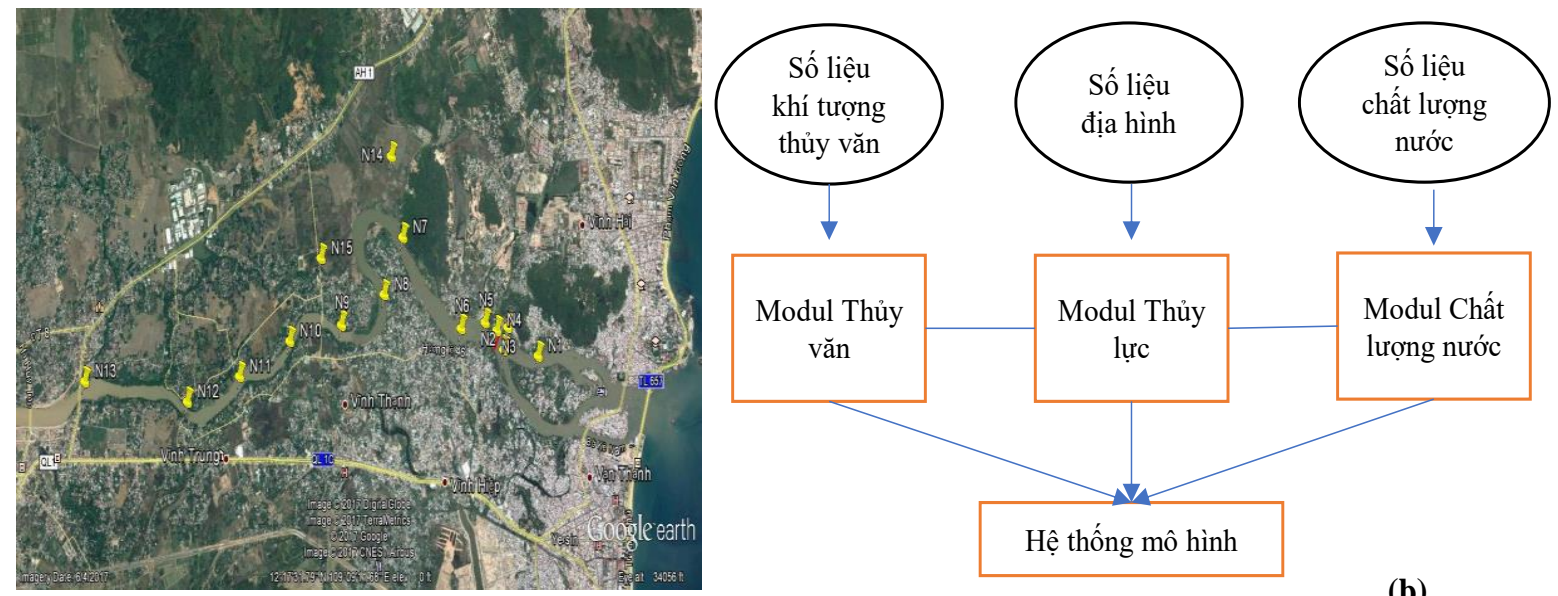

(a)

(b)

Hình 2. (a) Sơ đồ vị lấy mẫu nước; (b) Sơ đồ kết nối các mô hình lưu vực sông.

Mô đun Cross Section Editor có chức năng lưu trữ thông tin về các mặt cắt ngang. Cho phép nhập và chỉnh sửa dữ liệu địa hình dạng thô, các dữ liệu thô được nhập vào. Mô đun Boundary Editor sử dụng chỉnh sửa các điều kiện biên trong một mô hình MIKE11.

Mô đun QW ECOLab Editor là giao diện chính cho mô hình sinh thái và chất lượng nước sử dụng trong MIKE11. Bộ mô hình MIKE3 là một bộ phần mềm chuyên biệt cho kĩ thuật bao gồm hệ thống các mô hình không tách tời tính toán cho các trường dòng chảy bề mặt tự do dạng $2 \mathrm{D}$. Bộ phần mềm này có khả năng áp dụng cho tính toán thuỷ lực và các đặc trưng liên quan trong hồ, các vùng cửa sông, các vịnh, các vùng ven biển và các biển nơi mà sự phân tầng hoặc hoàn lưu theo phương thẳng đứng là quan trọng [13-18].

Trong khuôn khổ đánh giá chất lượng nước của sông Cái Nha trang, nghiên cứu lựa chọn mô hình MIKE 11 với mô-đun MIKE NAM để đánh giá chất lượng nước, đây là mô hình khá phổ biến và phù hợp với đánh giá diễn biến chất lượng nước sông [19-22].

Phần tính toán chất lượng nước với 6 mức độ khác nhau mô phỏng tính toán các quá trình chuyển hóa các hợp phần. Phần tính toán sinh thái cho phép tính tới 13 thông số sinh thái và các quá trình sinh học phức tạp. Các tác động của các yếu tố vật lý và địa lý như nhiệt độ, bức xạ mặt trời, điều kiện ánh sáng, độ muối và vị trí địa lý cũng được đưa vào mô hình.

Tính toán $\mathrm{DO}$ với các quá trình tương tác với ôxy khí quyển trên bề mặt, các quá trình hô hấp và quang hợp của sinh vật, quá trình ôxy chuyển ammonia thành nitrate, nhu cầu ôxy đáy.

Tính toán BOD thông qua các thông số lựa chọn, có thể tính toán được các hợp phần $\mathrm{BOD}$ riêng rẽ là $\mathrm{BOD}$ dạng lơ lửng và dạng hòa tan trong nước, $\mathrm{BOD}$ trong lớp bùn đáy. Mô hình còn cho phép tính toán các quá trình sinh hóa của $\mathrm{BOD}$ là phân rã $\mathrm{BOD}$, các quá trình chuyển hóa giữa các hợp phần BOD. 
Tính toán Phốt pho mô hình cho phép tính toán hai hợp phần riêng biệt là phốt pho vô và phốt pho hữu cơ, các quá trình sinh hóa xảy ra như nhận phốt pho từ phân rã $\mathrm{BOD}$, phốt pho chuyển hóa vào sinh vật, phân hủy phốt pho do vi khuẩn.

Tính toán Ammonia với quá trình sinh ra do phân hủy BOD, tiêu hao do chuyển hóa thành Nitrate, thực vật và vi khuẩn hấp thụ. Tính toán Nitrate với các quá trình sinh ra do chuyển hóa Ammonia, suy giảm do chuyển hóa thành Nitơ tự do.

Tính toán các hợp phần kim loại nặng và các chất rắn lơ lửng trong nước, các hợp phần kim loại nặng được phân ra và tính toán như sau: hợp phần kim loại tồn tại trong dạng kết dính với vật chất lơ lửng trong nước và trong lớp bùn; hợp phần kim loại tồn tại dạng ion trong nước và trong lớp bùn đáy. Các quá trình tương tác giữa chúng gồm chuyển hóa giữa các hợp phần trong nước, giữa các hợp phần trong lớp bùn đáy, và giữa các hợp phần trong nước và lớp bùn đáy. Các yếu tố tác động gồm độ $\mathrm{pH}$ của môi trường, nhiệt độ, các thành phần nguồn...

Ứng dụng mô hình MIKE11 tính toán chất lượng nước

Diện tích lưu vực sông tính từ thượng nguồn đến cửa sông là $1.900 \mathrm{~km}^{2}$, với chiều dài 79 km. Một số phụ lưu chính của sông: sông Khế, sông Giang, sông Cầu, sông Chò và suối Dầu, [3-5] được sơ đồ hóa tại (Hình 4b). Quá trình tính toán được thể hiện trên hình 3.

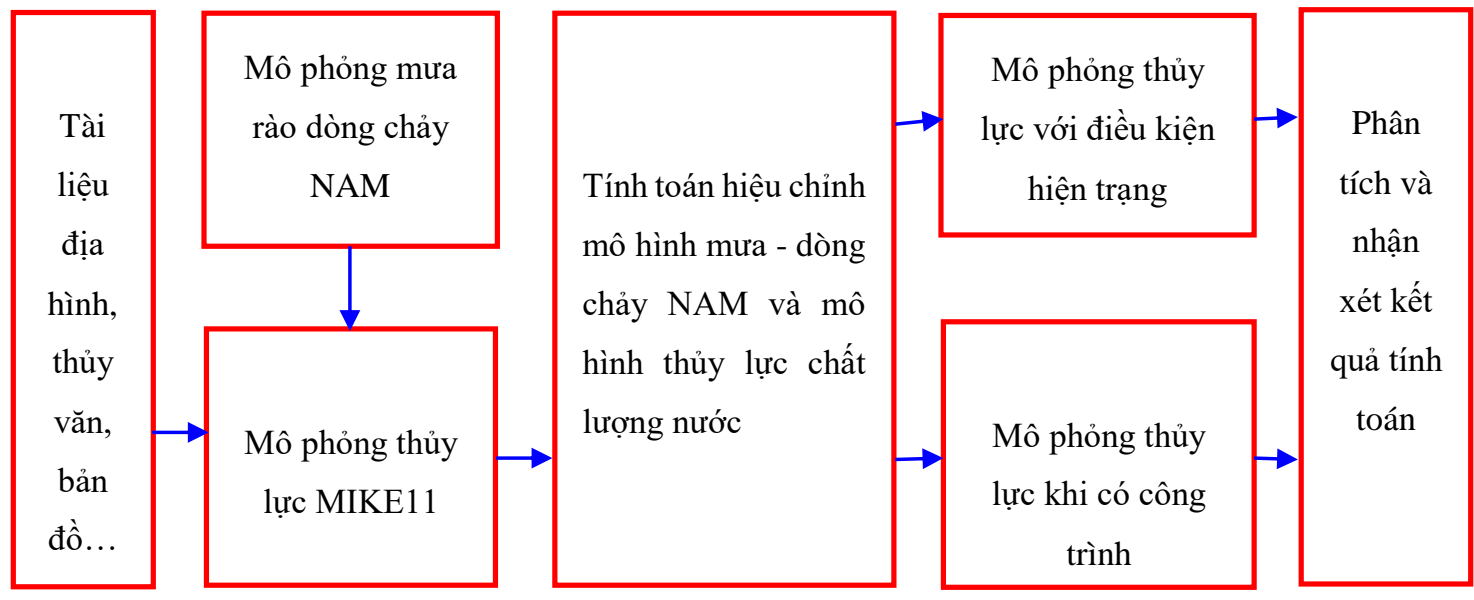

Hình 3. Sơ đồ tính toán chất lượng nước.

\subsection{Tài liệu tính toán}

2.3.1. Hệ thống trạm đo khí tượng, đo mưa

Có 5 trạm đo mưa trên lưu vực sông và số liệu được thu thập từ khoảng năm 1985 đến nay bao gồm bên Đắk Lắk.

Bảng 1. Hệ thống trạm đo sử dụng trong nghiên cứu.

\begin{tabular}{cccccc}
\hline \multirow{2}{*}{ TT } & \multirow{2}{*}{ Tên trạm } & \multicolumn{2}{c}{ Tọa độ } & \multirow{2}{*}{ Thò̀i kỳ quan trắc } & Địa điểm \\
\cline { 3 - 4 } & Vĩ độ & Kinh độ & & \\
\hline T1 & Nha trang & $12^{\circ} 13^{\prime}$ & $109^{\circ} 12^{\prime}$ & $1977-$ nay & P Vĩnh Nguyên, NT \\
T2 & Đồng trăng & $12^{\circ} 17^{\prime}$ & $108^{\circ} 56^{\prime}$ & $1977-$ nay & Diên thọ, Diên khánh \\
T3 & Khánh vĩnh & $12^{\circ} 17^{\prime}$ & $108^{\circ} 55^{\prime}$ & 1976 -nay & Thị trấn Khánh Vĩnh \\
T4 & Khánh sơn & $12^{\circ} 01^{\prime}$ & $108^{\circ} 58^{\prime}$ & $1977-$ nay & Khánh Sơn \\
T5 & M’ĐRắk & $12^{\circ} 44^{\prime}$ & $108^{\circ} 46^{\prime}$ & $1978-$ nay & Cư M’Ta, M'Đrắk \\
\hline
\end{tabular}

Do đặc điểm trên, trong tính toán mô hình, sử dụng các trạm đo phân bố trong lưu vực, có số liệu tốt. Như vậy, sử dụng 5 trạm đo (Nha Trang, Đồng Trăng, Khánh Vĩnh, Khánh Sơn và trạm MaĐrắk) để tính toán. Đối với bốc hơi, sử dụng trạm Nha Trang để tính toán [4]. 


\subsubsection{Tài liệu địa hình}

Các tài liệu địa hình được dùng trong tính toán với các tỷ lệ khác nhau. Với tỷ lệ lớn dùng DEM (bản đồ cao độ số) để phân chia các tiểu lưu vực trong vùng. Với các sông, dùng các mặt cắt để định dạng trong mô hình thuỷ lực.
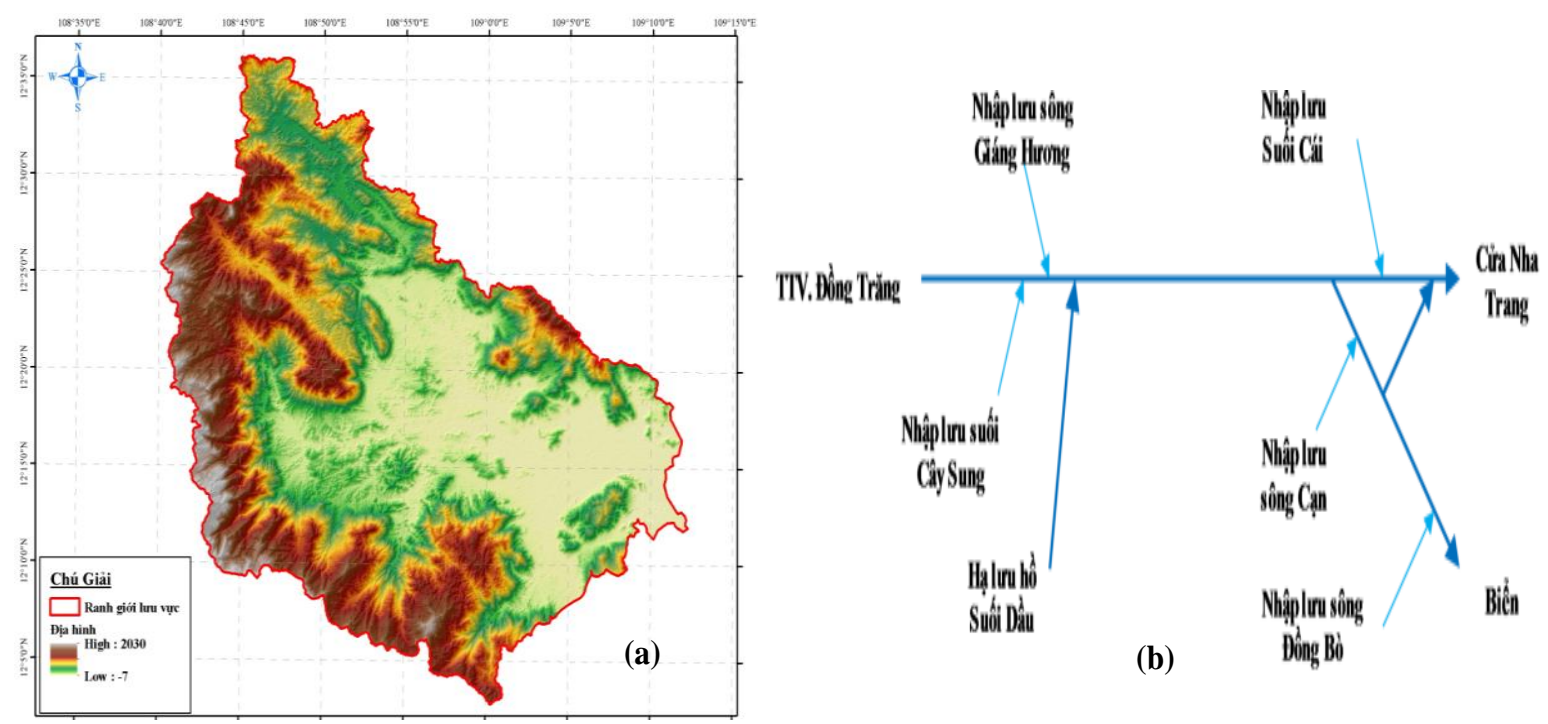

Hình 4. Bản đồ số hóa địa hình $1 / 10.000$ và sơ đồ hóa mạng lưới sông Cái Nha Trang: (a) Bản đồ số hóa địa hình 1/10.000 lưu vực sông Cái; (b) Sơ đồ hóa mạng lưới sông Cái.

\subsubsection{Tài liệu thủy văn}

Tài liệu thủy văn các trạm Nha Trang, Khánh Sơn, Khánh Vĩnh, Đồng Trăng và M’Đrắk do Đài Khí tượng Thủy văn khu vực Nam Trung Bộ cấp.

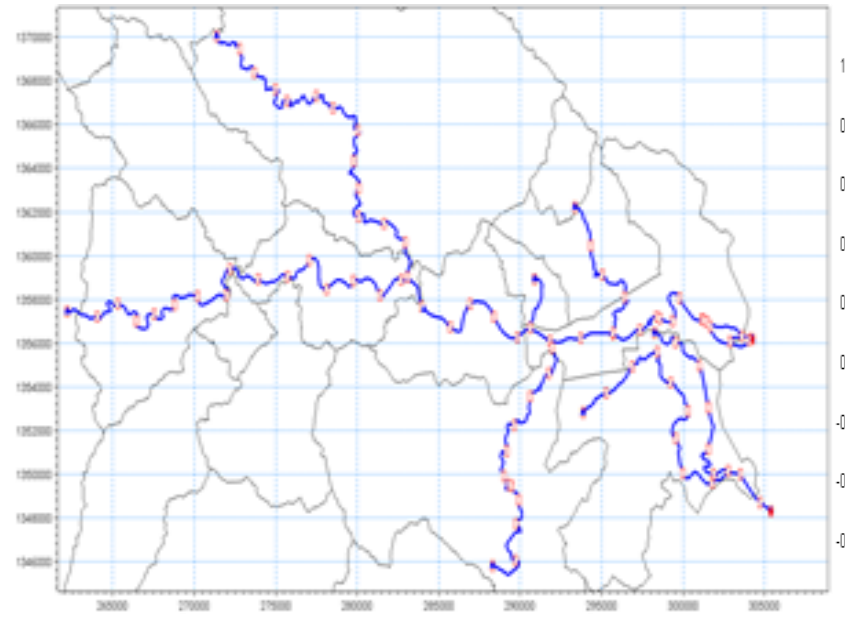

(a)

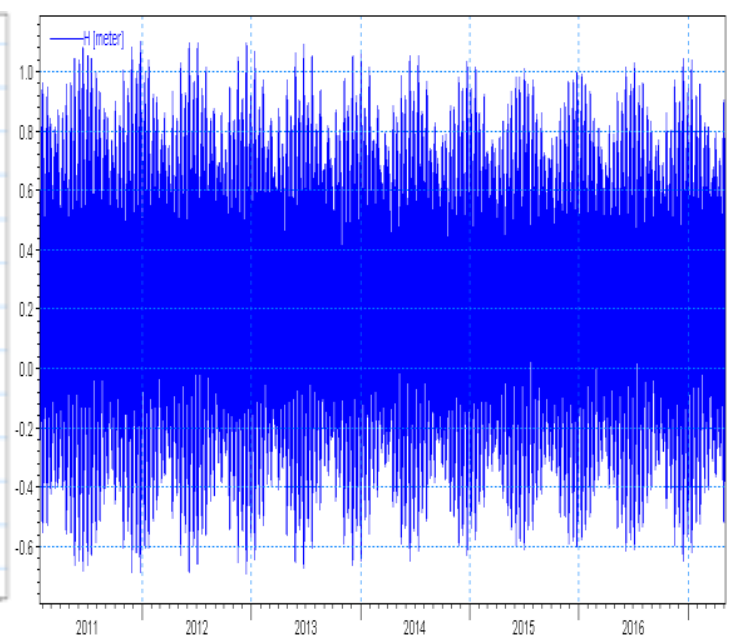

(b)

Hình 5. Vị trí đo đạc mặt cắt ngang và đường lưu lượng tại cửa sông Cái Nha Trang: (a) Vị trí đo đạc mặt cắt ngang sông; (b) Đường lưu lượng tại cửa SCNT.

Đặc điểm tự nhiên lưu vực sông Cái là vùng đồi núi nên chịu tác động chính từ dòng chảy thượng nguồn và phía dưới hạ lưu chịu tác động của mực nước triều. Biên lưu lượng gồm các biên lưu vực tính toán từ mô hình NAM. Biên mực nước được sử dụng từ biên mực nước triều Nha Trang. Biên chất lượng nước được xác định dựa vào các mầu phân tích thu thập được có vị trí gần biên tính toán vào mùa kiệt năm 2011 và mùa lũ năm 2017. 


\section{Kết quả nghiên cứu}

\subsection{Hiện trạng chất lượng nước sông Cái Nha trang}

Các thông số $\mathrm{pH}$, Nitrat, photphat, amoni và các kim loại nặng luôn đạt quy chuẩn cho phép; Nitrit, dầu mỡ và coliform tùy thời điểm và vị trí có giá trị vượt quy chuẩn. Mức ô nhiễm có khuynh hướng tăng dần từ thượng lưu về hạ lưu, hàm lượng Fe vượt quy chuẩn.

Vào mùa khô, độ mặn ảnh hưởng sâu vào đất liền từ $10-15 \mathrm{~km}$, mặn nhiễm lên đến nhà máy nước Xuân Phong làm ảnh hưởng đến cấp nước sinh hoạt cho Thành phố Nha Trang. Tiêu chuẩn quy định khi độ mặn dưới $250 \mathrm{mg} / 1$ mới được phép bơm dùng thì độ mặn tại bể nước thô ở trạm bơm Xuân Phong $>250 \mathrm{mg} / \mathrm{l}$. Mặn đã làm ảnh hưởng rất lớn đến việc cấp nước sinh hoạt, cấp nước tưới cho nông nghiệp ở ven sông Cái Nha Trang và một số ngành kinh tế, như Công ty Dệt Nha Trang do nước nhiễm mặn làm hư hỏng thiết bị và ảnh hưởng đến chất lượng nhuộm. Qua phân tích độ mặn nước sông Cái Nha Trang từ cầu Trần Phú đến cầu Vĩnh Phương của những năm gần đây cho thấy:

Thời gian triều cao: Độ mặn cực đại trên toàn tuyến năm 2016 là 32,95\%o, năm 2017 là 31,53\%o. Độ mặn cực tiểu trên toàn tuyến năm 2016 là 30,58\%o, năm 2018 là 31,55\%o.

Năm 2016 độ mặn trung bình cao nhất là $29,69 \%$, tại cầu Trần Phú; thấp nhất là $11,88 \%$, tại cầu Vĩnh Phương. Năm 2016 độ mặn trung bình cao nhất là 30,11\%o, tại cầu Trần Phú; thấp nhất là $17,81 \%$, tại cầu Gỗ Vĩnh Ngọc.

\subsection{Kết quả tính toán chất lương nước theo các kịch bản}

Bảng 2. Các kịch bản tính toán chất lượng nước.

\begin{tabular}{lll}
\hline 1 & Kịch bản 1 & $\begin{array}{l}\text { Tính toán với điều kiện chưa có công trình với năm kiệt lịch sử, nguồn nước xả ứng } \\
\text { với điều kiện hiện trạng } \\
\text { Tính toán với điều kiện chưa có công trình với năm kiệt lịch sử, nguồn nước xả ứng } \\
\text { với điều kiện quy hoạch trong tương lai } \\
\text { Tính toán với điều kiện có công trình với năm kiệt lịch sử, nguồn nước xả ứng với } \\
\text { điều kiện hiện trạng }\end{array}$ \\
\hline
\end{tabular}

Để xác định năm kiệt nhất vùng nghiên cứu, sử dụng tài liệu tổng lượng dòng chảy 33 năm tại trạm đo thủy văn Đồng Trăng để tính toán. Tài liệu này xác định lưu lượng trung bình tháng nhiều năm và tháng có lưu lượng nhỏ nhất vào tháng 4 với khoảng hơn $24,2 \mathrm{~m}^{3} / \mathrm{s}$.
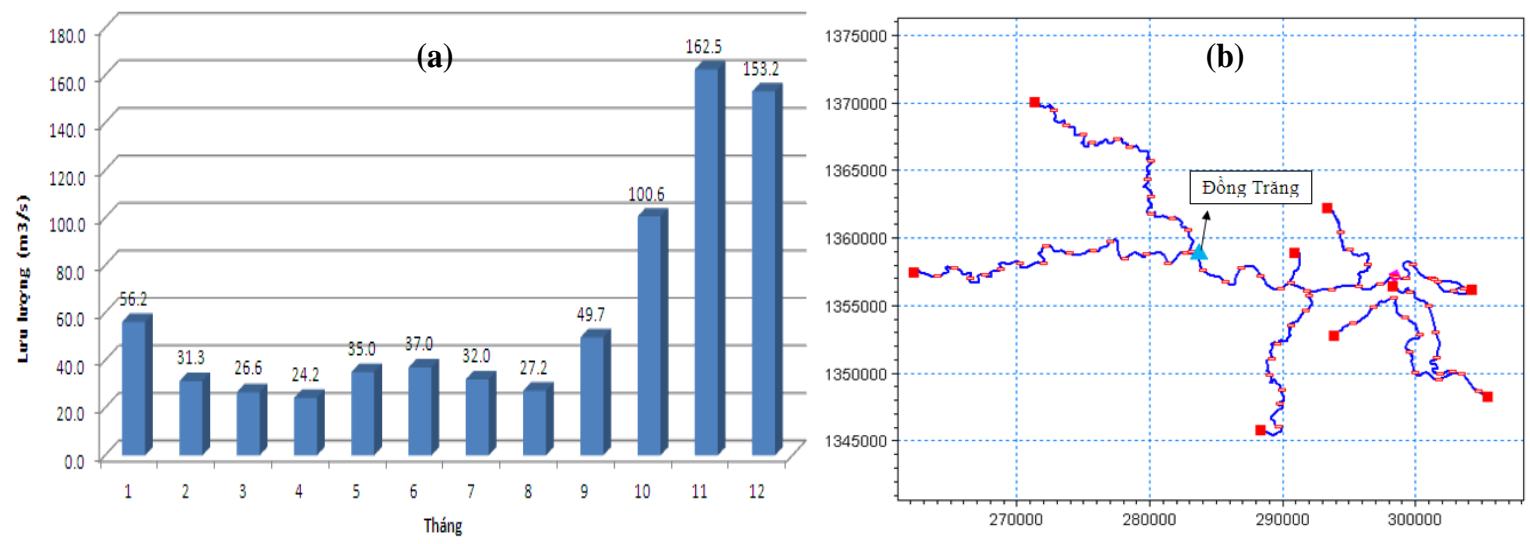

Hình 6. (a) Lưu lượng trung bình sông Cái; (b) Vị trí đo đạc thủy văn lưu vực sông Cái.

Sau khi xác định được lưu lượng trung bình tháng thấp nhất trong 1 năm, dựa trên liệt tài liệu 33 năm tại Đồng Trăng ta tính toán được ứng với lưu lượng trung bình tháng 4 hàng năm thì xác định lưu lượng trung bình tháng 4 năm 2017 có giá trị nhỏ nhất khoảng $1,3 \mathrm{~m}^{3} / \mathrm{s}$ qua đó xác định năm kiệt nhất tại vùng nghiên cứu là năm 2017. 


\subsection{Tính toán theo kịch bản 1 và 3}

Trong trường hợp hiện trạng, năm 2017 là năm kiệt nhất dòng chảy trên sông cái khá nhỏ so với mọi năm, và mùa kiệt năm 2017 kéo dài, chất lượng nước sông cũng thay đổi nhiều.

Mùa kiệt năm 2016 có thời gian kéo dài tới đầu tháng 7 , chất lượng nước trong sông khi lượng thải đổ ra sông không được làm sạch nên nồng độ các chất ô nhiễm đạt giá trị lớn nhất vào cuối tháng 6 như BOD: $5,73 \mathrm{mg} / 1$, TSS: $29,2 \mathrm{mg} / 1$, tổng $\mathrm{N}$ : 1,97 mg/l, tổng P: 0,332 mg/l.

Trong điểu kiện hiện trạng có thể thấy chế độ dòng chảy tác động khá lớn tới chất lượng nước trong sông, năm 2016 mùa kiệt kéo dài, lưu lượng dòng chảy nhỏ đã làm chất lượng nước sông thời kì mùa kiệt kéo dài ô nhiễm tăng cao.
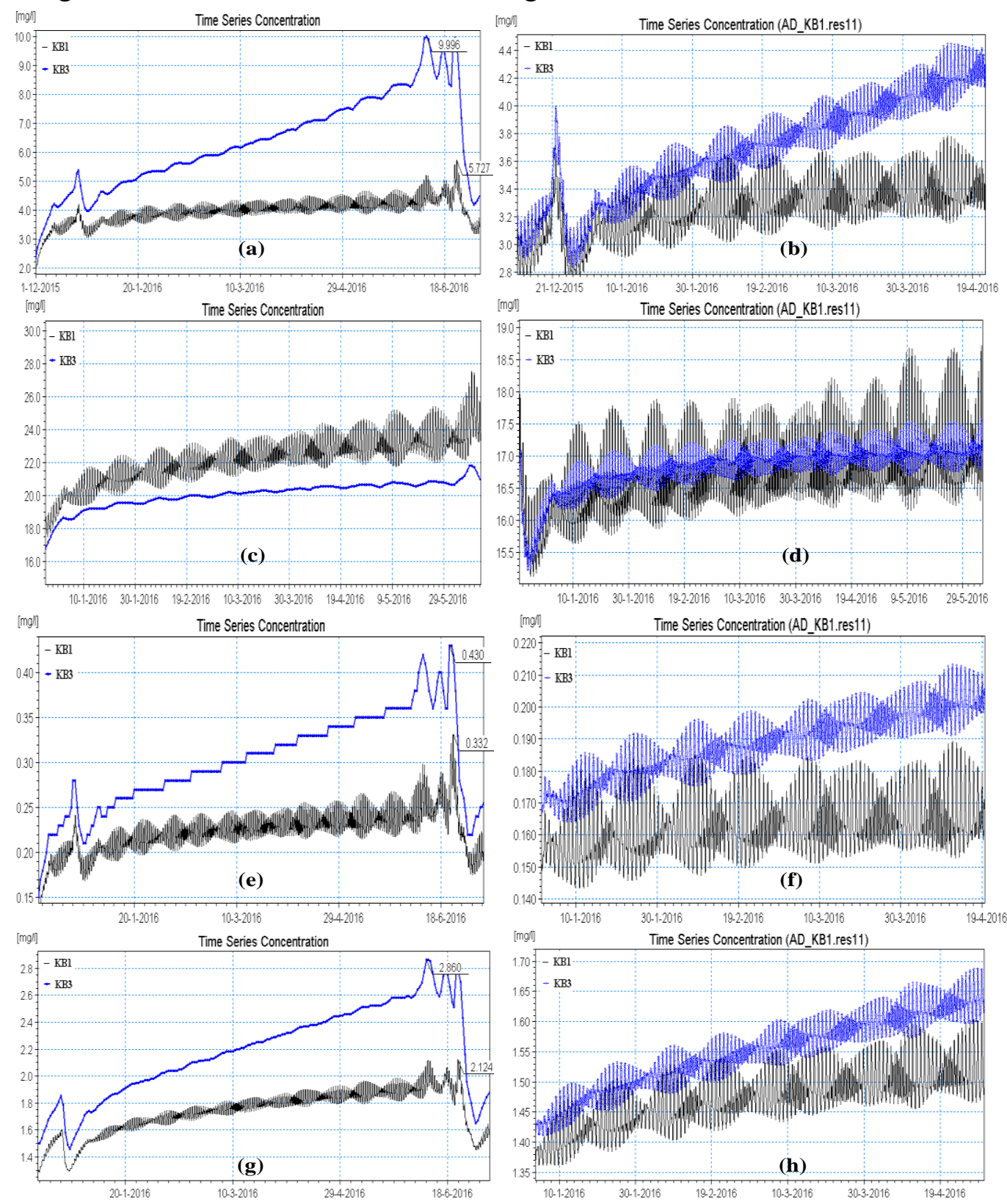

Hình 7. (a) Nồng độ $\mathrm{BOD}$ mô phỏng theo kịch bản 1 và kịch bản 3 phía thượng lưu; (b) Nồng độ BOD mô phỏng theo kịch bản 1 và kịch bản 3 phía hạ lưu; (c) Nồng độ TSS mô phỏng theo kịch bản 1 và kịch bản 3 phía thượng lưu; (d) Nồng độ TSS mô phỏng theo kịch bản 1 và kịch bản 3 phía hạ lưu; (e) Nồng độ Tổng $\mathrm{P}$ mô phỏng theo kịch bản 1 và kịch bản 3 phía thượng lưu; (f) Nồng độ Tổng $\mathrm{P}$ mô phỏng theo kịch bản 1 và kịch bản 3 phía hạ lưu; $(\mathrm{g})$ Nồng độ Tổng $\mathrm{N}$ mô phỏng theo kịch bản 1 và kịch bản 3 phía thượng lưu; (h) Nồng độ Tổng $\mathrm{N}$ mô phỏng theo kịch bản 1 và kịch bản 3 phía hạ lưu. 


\subsection{Tính toán theo kịch bản 1 và 2}

Khi xây dựng xong đập, chế độ dòng chảy, chất lượng nước trên sông thay đổi và làm cho nồng độ các chất hạ lưu thay đồi khá nhiều. Với việc vận hành cống mở khi nồng độ các chất tại vị trí cống phía thượng lưu sẽ giảm đi đáng kể, nồng độ $\mathrm{BOD}_{5} \mathrm{sau}$ khi đạt tới $6 \mathrm{mg} / \mathrm{l}$ mở cống để giảm nồng độ, khơi thông dòng chảy hạ lưu làm cho môi trường nước sạch hơn.

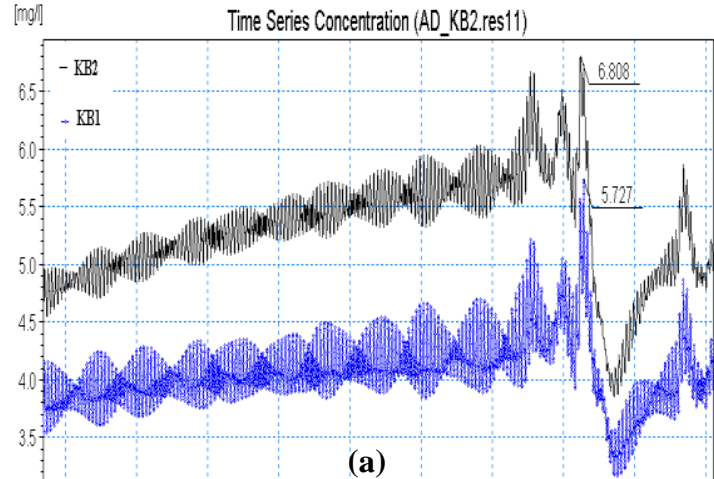

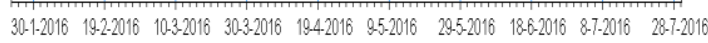

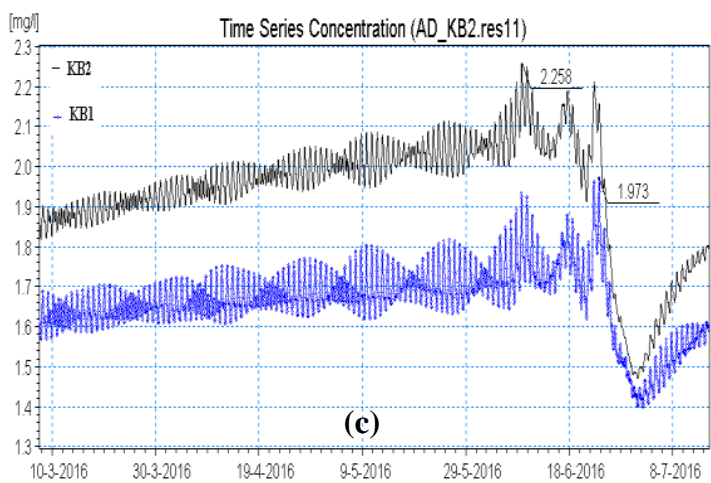

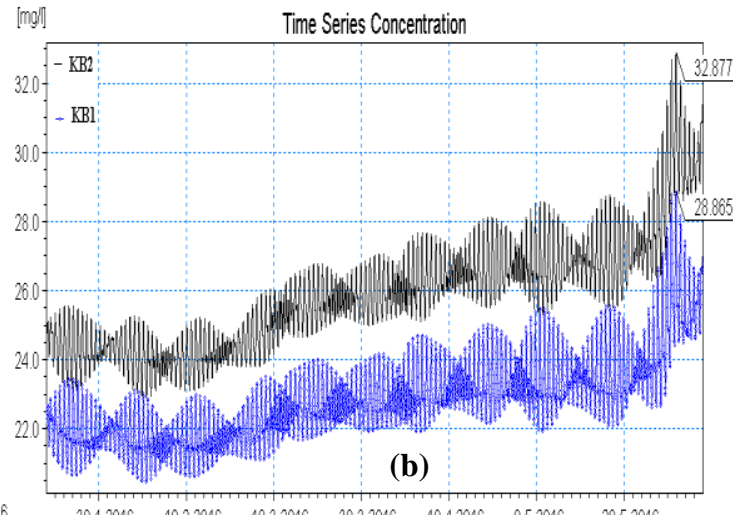

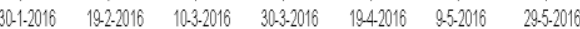
[moll] Time Series Concentration (AD_KB2.res11)

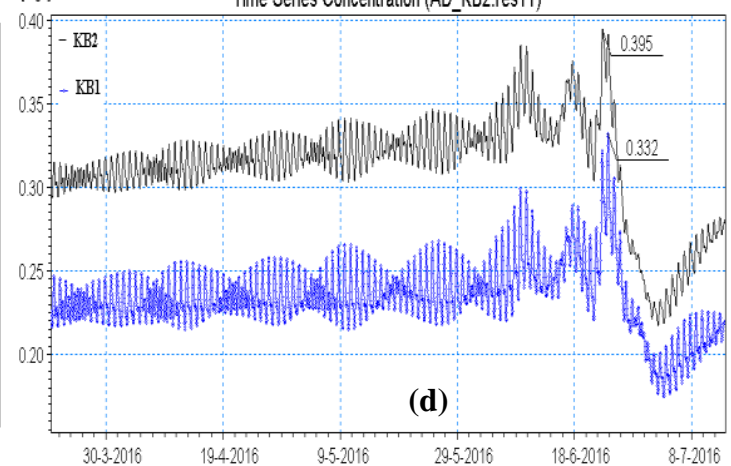

Hình 8. (a) Nồng độ $B O D$ mô phỏng theo $K B 1$ và $K B 2$; (b) Nồng độ TSS mô phỏng theo KB1 và $\mathrm{KB} 2$; (c) Nồng độ Tổng $\mathrm{N}$ mô phỏng theo $\mathrm{KB} 1$ và $\mathrm{KB} 2$; (d) Nồng độ Tổng $\mathrm{P}$ mô phỏng theo $\mathrm{KB} 1$ và $\mathrm{KB} 2$.

Diễn biến nồng độ BOD như hình trên có thể thấy khi mở cống thì nồng độ BOD giảm xuống khá nhiều tại vị trí công trình làm cho chất lượng nước tốt hơn với giá trị nồng độ BOD giảm từ $6 \mathrm{mg} / \mathrm{l}$ xuống còn hơn $4 \mathrm{mg} / 1$ và thay vào đó khi mở cống tác động bởi triều cũng ảnh hưởng tới chất lượng nước và làm cho biên độ dao động của nồng độ cũng biến thiên theo dòng triều.

Khi vận hành công trình, với thời giam bắt đầu mở cống cho đến khi nồng độ $\mathrm{BOD}$ giảm xuống còn 4,5 mg/l phải mất khoảng thời gian từ 5-6 ngày do vậy cần mở cống vào thời kì triều cường thấp để quá trình làm cho chất lượng nước tốt vùng thượng lưu được nhanh hơn. Trong trường hợp mùa kiệt cần phải giữ nước ngọt phía thượng lưu thì chỉ cần mở cống 1 ngày để đảm bảo giải phóng các chất bồi tụ trước cửa cống giảm ô nhiễm chất lượng nước tạm thời (Hình 8$)$. Nồng độ $\mathrm{BOD}_{5}$ ở hạ lưu công trình cũng giảm mạnh khi mở cống và biên độ dao dộng cũng tăng lên hơn so với khi đóng cống do quá trình dòng chảy lưu thông tại cống. Với nồng độ Tổng $\mathrm{N}$ và Tổng $\mathrm{P}$ trong nước ở vị trí công trình phía thượng lưu sau khi mở cống cũng giảm khá nhiều với nồng độ Tổng $\mathrm{N}$ trong cùng thời gian mở cống giảm từ 1,8 $\mathrm{mg} / \mathrm{l}$ xuống còn khoảng hơn $1,6 \mathrm{mg} / \mathrm{l}$ trong thời gian từ $5-6$ ngày và nồng độ Tổng $\mathrm{P}$ tại vị trí thượng lưu công trình cũng giảm từ $0,26 \mathrm{mg} / 1$ xuống còn khoảng $0,23 \mathrm{mg} / \mathrm{l}$ trong thời gian từ 5-6 ngày. Khi mở cống, dòng chảy qua cống chảy siết và có vận tốc cao qua đó làm đo lưu lượng phía thượng lưu đổ dồn xuống hạ lưu cống. Dòng chảy cuốn theo bùn cát và các chất trong nước cuốn theo làm cho độ đục trong dòng chảy bị đảo lộn và tăng lên qua đó làm cho diễn biến về chỉ số TSS trong nước tại vị trí công trình khi mở cống cũng tăng lên đáng kể. 
Mặt khác khi cống mở dòng triều ngoài biển tác động lên phía thượng lưu cũng làm cho các chất trong nước bị tác động khá nhiều qua đó biên độ dao động của các chất cũng bị ảnh hưởng. Như vậy theo như hình vẽ dưới miêu tả được quá trình diễn biến chỉ số TSS bị ảnh hưởng khá nhiều khi mở cống làm cho tăng lên theo cả giá trị cũng như biên độ dao động.

\section{2. Đánh giá ảnh hương của công trình đến xâm nhập mặn}

Theo kết quả mô phỏng, khi xây dựng công trình và vận hành đóng cống vào mùa kiệt thì hầu hết khu vực phía thượng lưu sông Cái sau cống không bị ảnh hưởng bởi chế độ thủy triều ngoài biển, do đó nồng độ mặn cũng không tác động từ ngoài biển vào. So sánh kết quả nồng độ mặn tại vị trí Cầu Gỗ (Vĩnh Ngọc) sau công trình thấy rõ được nồng độ mặn tại vị trí này hẩu hết được ngọt hóa và không bị xâm nhập mặn từ ngoài biển tác động vào (Hình 9b).
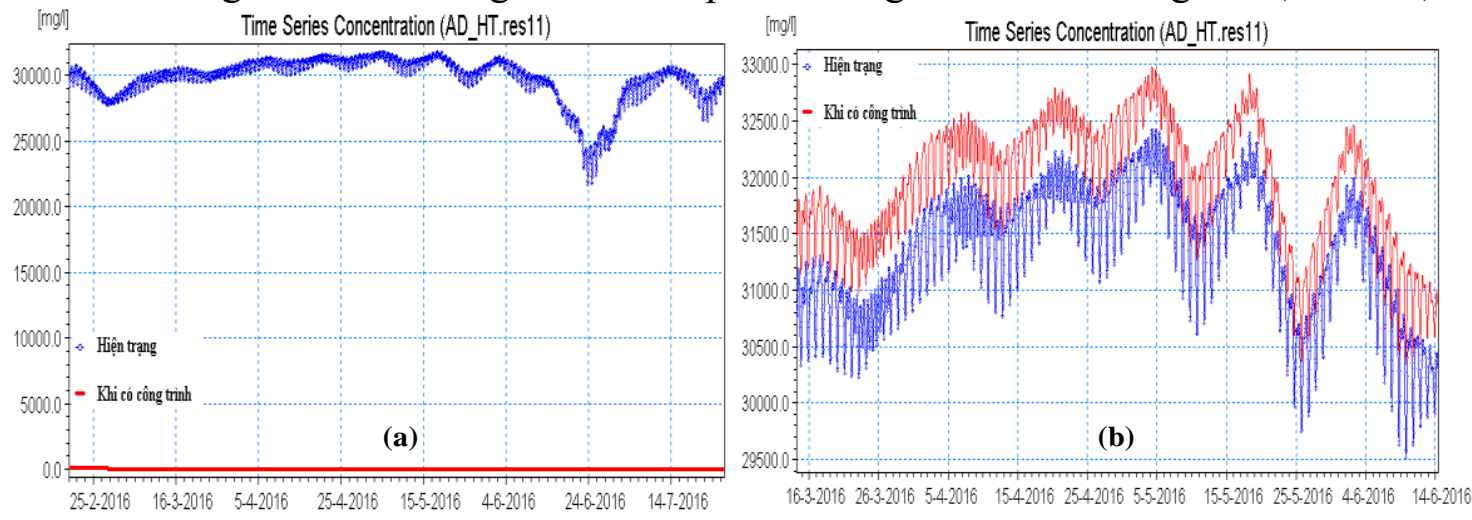

Hình 9. Diễn biến độ mặn sông Cái Nha Trang trước và sau khi có đập ngăn mặn: (a) Độ mặn tại trạm Cầu Gỗ (Vĩnh Ngọc) hiện trạng và khi có đập ngăn mặn; (b) Độ mặn mô phỏng sau đập theo hiện trạng và khi có đập ngăn mặn.

Sau khi xây dựng công trình và đóng cống ngăn mặn trong thời gian mùa kiệt, đã một phần chặn dòng triều ngoài biển mặt khác cũng ngăn dòng chảy phía thượng lưu vào mùa kiệt đổ ra biển. Qua đó nồng độ mặn phía sau công trình về phía hạ lưu trong thời đoạn này có khả năng tăng cao hơn so với khi chưa xây dựng công trình. Diễn biến nồng độ mặn khi xây dựng công trình phía sau công trình bị ảnh hưởng bởi chế độ thủy triều, nhưng biên độ dao động tại thời điểm này không lớn như so với hiện trạng, nhưng về giá trị thì cả chân và đỉnh triều, nồng độ mặn thường cao hơn so với hiện trạng khoảng $0,5 \%$.

\subsection{Hiệu chỉnh mô hình}

\subsubsection{Hiệu chỉnh mô hình thủy lực}

Việc hiệu chỉnh mô hình thủy lực sử dụng tài liệu đo đạc vào tháng 11 năm 2017 với số liệu tại 3 trạm trên sông Cái (Hình 10a). Kết quả so sánh lưu lượng thực đo và mô phỏng tại trạm thủy văn $\mathrm{T} 1$ được thể hiện trên hình $10 \mathrm{~b}$.
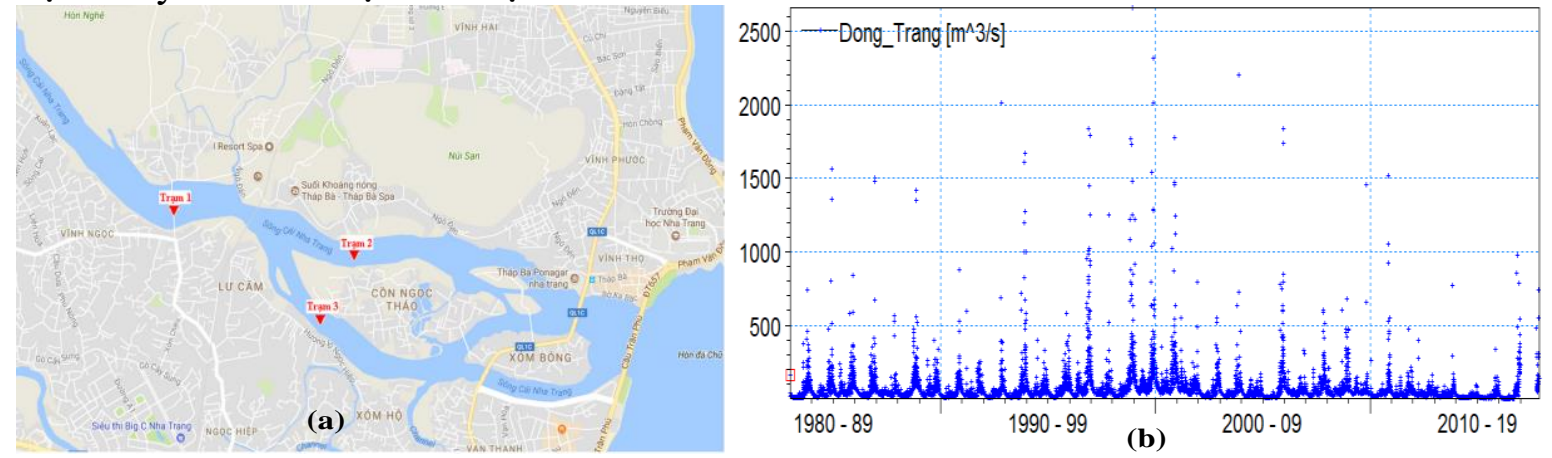

Hình 10. (a) Vị trí hiệu chỉnh mô hình thủy lực; (b) Lưu lượng thực đo và mô phỏng tại trạm thuỷ văn T1. 
Kết quả tính toán mô phỏng về chế độ thủy lực trên sông Cái cho thấy, kết quả hiệu chỉnh với tài liệu đo đạc khá tương đồng và đạt kết quả cao (Hình 12a-12b, Bảng 3). Như vậy có thể đảm bảo mô phỏng chất lượng nước khu vực nghiên cứu.
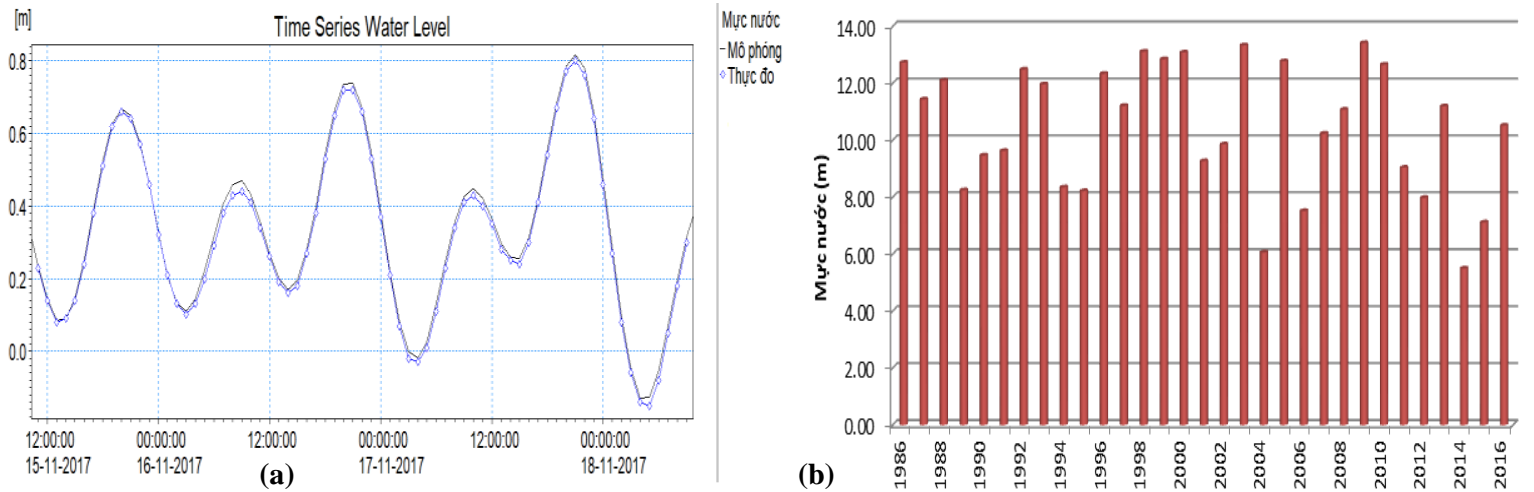

Hình 12. (a) Mực nước thực đo và mô phỏng tại trạm thuỷ văn T2; (b) Mực nước lớn nhất tại trạm thuỷ văn T3.

Bảng 3. Bảng tính toán hệ số tương quan giữa số liệu thực đo và mô phỏng.

\begin{tabular}{cccccc}
\hline STT & Trạm & Yếu tố & Hệ số tương quan & Sai số đỉnh & $\begin{array}{c}\text { Hệ số NSE } \\
\text { (Nash-Sutcliffe) }\end{array}$ \\
\hline 1 & Trạm T1 & H & 0,96 & 0,94 & 0,92 \\
2 & Trạm T2 & H & 0,96 & 0,94 & 0,92 \\
3 & Trạm T3 & H & 0,96 & 0,94 & 0,92 \\
4 & Trạm T1 & Q & 0,89 & 0,91 & 0,90 \\
5 & Trạm T2 & Q & 0,91 & 0,89 & 0,89 \\
6 & Trạm T3 & Q & 0,92 & 0,88 & 0,92 \\
7 & Trạm T1 & V & 0,89 & 0,90 & 0,89 \\
8 & Trạm T2 & V & 0,87 & 0,90 & 0,90 \\
9 & Trạm T3 & V & 0,86 & 0,85 & 0,86 \\
\hline
\end{tabular}

\subsubsection{Hiệu chỉnh mô hình chất lượng nước}

Các tài liệu đo đạc chất lượng nước trong quá trình mô phỏng, hiệu chỉnh các thông số của mô hình phù hợp với kết quả thực đo trong tháng 11 năm 2017 (Hình 13-14).
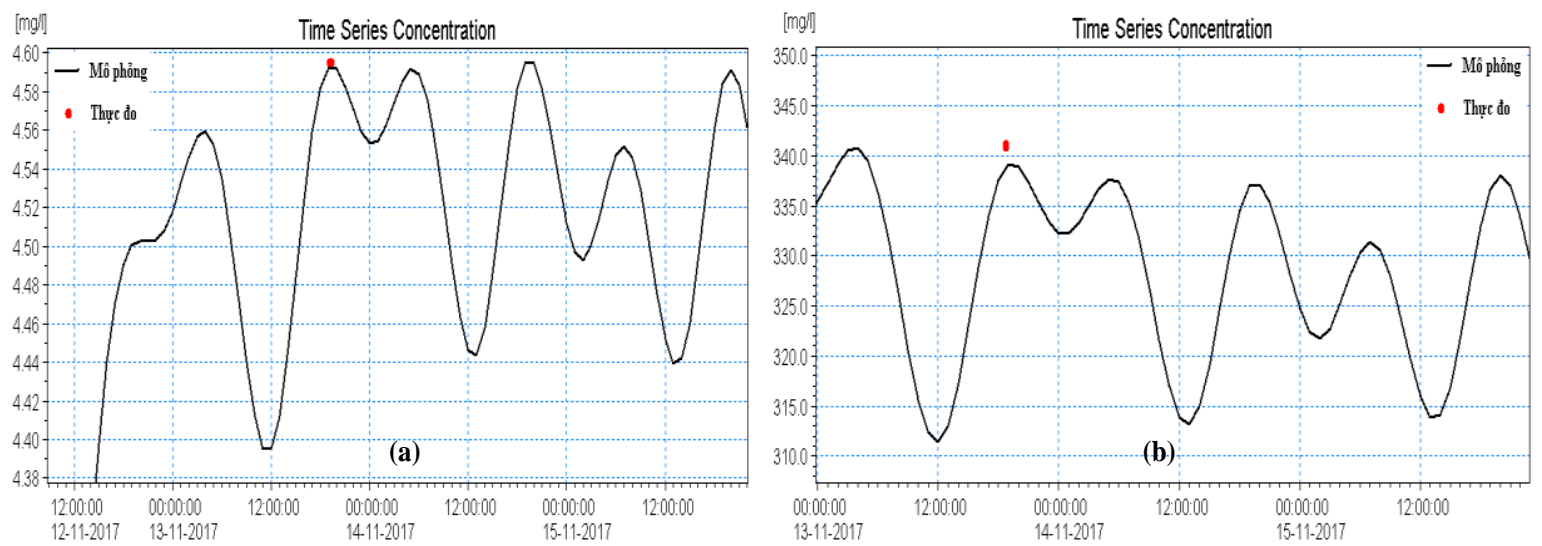

Hình 13. Thông số BOD thực đo và mô phỏng tại trạm N1 (Thượng lưu); Thông số TSS thực đo và mô phỏng tại trạm N1 (Thượng lưu). 

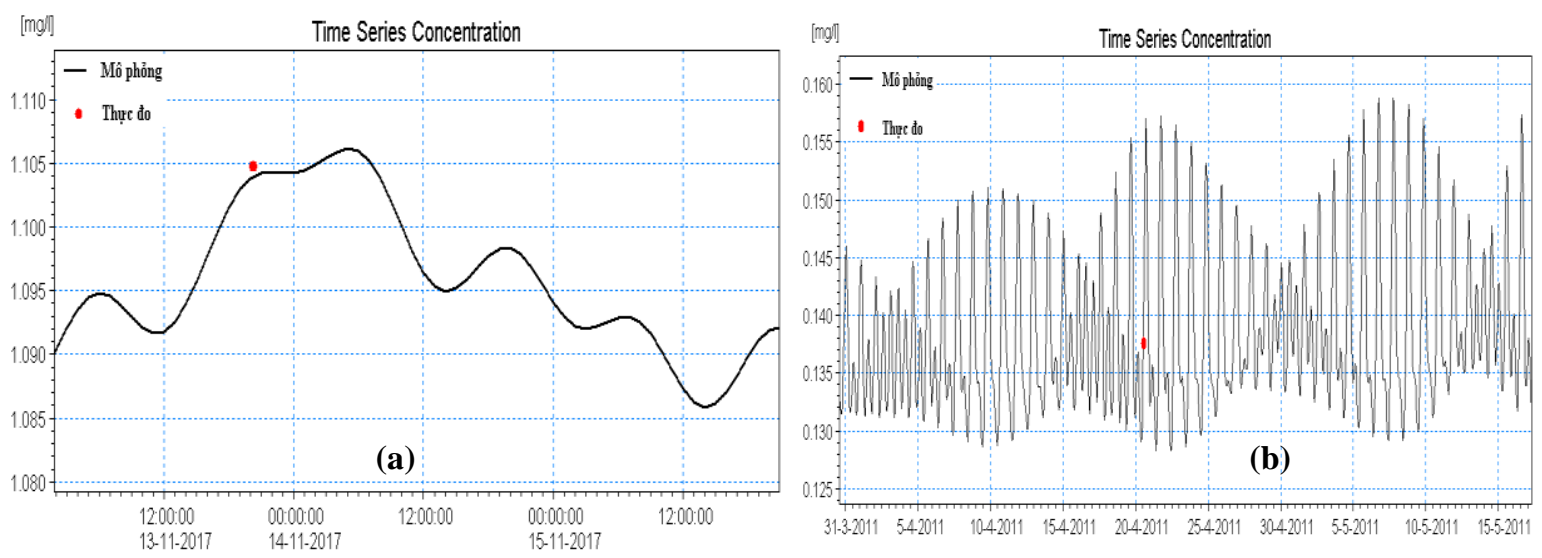

Hình 14. (a) Thông số $\mathrm{N}$ thực đo và mô phỏng tại trạm N7 (Hạ lưu); (b) Thông số $\mathrm{P}$ thực đo và mô phỏng tại trạm N1 (Thượng lưu).

\subsubsection{Kiểm định mô hình chất lượng nước}

Sau khi hiệu chỉnh mô hình đạt kết quả khá tương đồng với kết quả thực đo, thực hiện kiểm định mô hình kết quả mô phỏng về một số chỉ tiêu tại các vị trí đo đạc trên sông Cái đạt được tương đồng so với giá trị thực đo, chênh lệch giữa các giá trị mô phỏng và thực đo là không nhiều. Tuy nhiên cũng có một số vị trí chỉ số chất lượng nước mô phỏng có mức độ chênh lệch lớn so với giá trị thực đo nhưng trên tổng thể thì kết quả mô phỏng là chấp nhận được và có thể sử dụng để mô phỏng các kịch bản tính toán (Bảng 4).

Bảng 4. Giá trị TSS, tổng $\mathrm{P}$, tổng $\mathrm{N}$ và $\mathrm{BOD}_{5}$ mô phỏng và thực đo tại các vị trí trên sông Cái.

\begin{tabular}{|c|c|c|c|c|c|c|c|c|c|c|c|c|}
\hline \multirow[b]{2}{*}{ TT } & \multicolumn{3}{|c|}{ TSS (mg/l) } & \multicolumn{3}{|c|}{ Tổng P (mg/l) } & \multicolumn{3}{|c|}{ Tổng N (mg/) } & \multicolumn{3}{|c|}{ BOD5 $_{\text {(mg/l) }}$} \\
\hline & $\begin{array}{c}\text { Thực } \\
\text { do }\end{array}$ & $\begin{array}{c}\text { Mô } \\
\text { phỏng }\end{array}$ & $\begin{array}{l}\text { Chên } \\
\text { h lệch }\end{array}$ & $\begin{array}{c}\text { Thục } \\
\text { đo }\end{array}$ & $\begin{array}{c}\text { Mô } \\
\text { phỏng }\end{array}$ & $\begin{array}{c}\text { Chênh } \\
\text { lệch }\end{array}$ & $\begin{array}{l}\text { Thự } \\
\text { c đo }\end{array}$ & $\begin{array}{c}\text { Mô } \\
\text { phỏng }\end{array}$ & $\begin{array}{l}\text { Chênh } \\
\text { lệch }\end{array}$ & $\begin{array}{c}\text { Thực } \\
\text { do }\end{array}$ & $\begin{array}{c}\text { Mô } \\
\text { phỏng }\end{array}$ & $\begin{array}{c}\text { Chênh } \\
\text { lệch }\end{array}$ \\
\hline 1 & 23,9 & 24,6 & $-0,65$ & 0,042 & 0,06 & $-0,018$ & 1,51 & 1,62 & $-0,11$ & 2,86 & 2,81 & 0,05 \\
\hline 2 & 42,5 & 40,5 & 2,06 & 0,135 & 0,14 & $-0,005$ & 2,28 & 2,37 & $-0,09$ & 3,31 & 3,33 & $-0,02$ \\
\hline 3 & 35,2 & 38,2 & $-2,92$ & 0,125 & 0,13 & $-0,005$ & 1,63 & 1,45 & 0,18 & 4,27 & 4,58 & $-0,31$ \\
\hline 4 & 26,9 & 27,6 & $-0,67$ & 0,113 & 0,09 & 0,023 & 2,25 & 2,08 & 0,17 & 4,05 & 3,97 & 0,08 \\
\hline 5 & 8,76 & 9,02 & $-0,26$ & 0,061 & 0,056 & 0,005 & 1,28 & 1,32 & $-0,04$ & 2,18 & 2,57 & $-0,39$ \\
\hline 6 & 28,7 & 29,3 & $-0,53$ & 0,095 & 0,12 & $-0,025$ & 5,93 & 5,22 & 0,71 & 4,13 & 5,35 & $-1,22$ \\
\hline
\end{tabular}

\section{Kết luận}

Khi chưa xây dựng công trình cho thấy nồng độ các chỉ tiêu hóa lý tại khu vực nghiên cứu với chế độ dòng chảy hiện trạng đều tăng lên theo thời gian do dân số tăng lên cùng với việc kinh tế phát triển đã làm cho lượng thải ra môi trường tăng cao.

Khi xây dựng công trình, tại vị trí thượng lưu công trình khi đóng cống thì hầu hết các thông số như $\mathrm{BOD}_{5}$, Tổng $\mathrm{N}$, Tổng $\mathrm{P}$ trong trường hợp hiện trạng và tương lai đều tăng lên đáng kể và mức độ tăng của các thông số này cũng tăng dần theo thời gian trong cả mùa kiệt. Với thông số TSS khi đóng cống lại làm cho chế độ dòng chảy không còn lưu thông như trước nữa, do đó chỉ số TSS hầu như nhỏ hơn so với khi chưa xây dựng công trình. Thông số $\mathrm{BOD}_{5}$ giảm từ 8,5 xuống còn $4,5 \mathrm{mg} / \mathrm{l}$. Vị trí hạ lưu phía sau công trình khi đóng cống lại thì hình thành phía sau công trình ra tới biển như một kênh cụt và chỉ chịu tác động bởi dòng triều ngoài biển, do đó các chỉ tiêu hóa lý ngay tại vị trí phía sau công trình tăng lên so với khi chưa xây dựng. 
Độ mặn trung bình toàn tuyến của năm 2017 21,57\%o với độ lệch chuẩn là 3,89 cao hơn độ mặn trung bình toàn tuyến của năm 2018 là 20,16 với độ lệch chuẩn là 7,89 . Khi xây dựng công trình và vận hành đóng cống vào mùa kiệt thì hầu hết khu vực phía thượng lưu sông Cái sau cống không bị ảnh hưởng bởi chế độ thủy triều ngoài biển, nồng độ mặn $<4 \%$. Công tác cấp nước xử lý nước sinh hoạt cho Thành phố Nha Trang, huyện Diên Khánh, Khánh Vĩnh... và phục vụ sản xuất nông nghiệp thuận lợi.

Việc áp dụng mô hình MIKE11 đã dùng bộ số liệu trong nhiều năm để làm cơ sở dữ liệu cho mô hình tính toán. Trong mô hình tính toán cũng đã hiệu chỉnh với các mẫu phân tích chất lượng nước mùa lũ năm 2017 và kiểm định mùa kiệt năm 2011 đạt được kết quả khá tương đồng so với giá trị thực đo ngoài hiện trường. Qua đó thấy được kết quả nghiên cứu cung cấp đầy đủ, chính xác về hiện trạng môi trường nước của lưu vực sông Cái Nha Trang góp phần vào sự phát triển kinh tế xã hội, quản lý và bảo vệ môi trường tỉnh Khánh Hòa.

Đóng góp của tác giả: Xây dựng ý tưởng nghiên cứu: H.P.; Đ.V.Đ.; N.L.N.T.; V.H.D.; Chọn phương pháp nghiên cứu: H.P.; ĐVĐ.; N.L.N.T.; V.H.D.; Xử lý số liệu: H.P.; ĐVĐ.; N.L.N.T.; Lấy mẫu: Đ.V.Đ.; V.H.D.; N.L.N.T.; Phân tích mẫu: N.L.N.T.; V.H.D.; Viết bản thảo bài báo: H.P.; ĐVĐ.; N.L.N.T.; Chỉnh sửa bài báo: H.P.; V.H.D.

Lời cảm ơn: Nghiên cứu này được tài trợ của Viện phát triển Công nghệ Môi trường và Tài nguyên nước Phú mỹ, Mã số PHUMYTECH 02.18.

Lời cam đoan: Tác giả cam đoan bài báo này là công trình nghiên cứu của tôi từ công tác nghiên cứu của Viện PHUMYTECH, chưa được công bố ở đâu, không sao chép từ những nghiên cứu trước đây; không có sự tranh chấp.

\section{Tài liệu tham khảo}

1. Đài Khí tượng Thủy văn (KTTV) khu vực Nam Trung Bộ. Nghiên cứu bổ sung đặc điểm Khí hậu Thủy văn tỉnh Khánh Hòa, 2011.

2. Sở Nông nghiệp và Phát triển Nông thôn tỉnh Khánh Hòa. Dự án: "Lập bản đồ ngập lụt lưu vực sông Dinh Ninh Hòa và sông Cái Nha Trang”, 2011.

3. Quyết, N.K. Nghiên cứu giải pháp cải thiện tình hình dòng chảy sau khi xây dựng các công trình kè và đường, chỉnh trang đô thị dọc bờ sông Cái Nha Trang, 2017.

4. Sở Tài nguyên và Môi trường Khánh Hòa. Báo cáo hiện trạng môi trường tỉnh Khánh Hòa giai đoạn 2011-2015, 2016.

5. Trung tâm khí tượng, thủy văn tỉnh Khánh Hòa. Báo cáo đo đạc thủy văn trên địa bàn tỉnh Khánh Hòa, 2018.

6. Cục thống kê Khánh hòa. Niên giám thống kê năm 2017, 2018, Tỉnh Khánh hòa.

7. Phú, H. Nghiên cứu xây dựng bộ số liệu cho việc ứng dụng mô hình toán mô phỏng diễn biến chất lượng nước sông La Ngà Bình Thuận. Tạp chí Khí tượng Thủy văn 2018, 632, 26-32.

8. Phú, H. Tác động của công trình hồ đập tới dòng chảy hạ lưu sông La Ngà, ứng dụng mô hình thủy văn, thủy lực phục hồi dòng chảy tự nhiên sau khi có hồ chứa Đa Mi-Hàm Thuận. Tạp chí Khí tượng Thưy văn 2018, 686, 01-11.

9. Viện Kỹ thuật Biển. Báo cáo tổng hợp đề tài: Đánh giá hiện trạng môi trường lưu vực sông Cái (Nha Trang) và sông Dinh (Ninh Hòa), phân tích nguyên nhân và đề xuất các giải pháp bảo vệ, cải thiện chất lượng môi trường, 2012. 
10. Lương Văn Thanh và cs. Úng dụng các biện pháp công trình và phi công trình để cái tạo các vùng đất bị bỏ hóa ở Duyên Hải Nam Trung Bộ do đào ao nuôi trồng thủy sản không đúng kỹ thuật thành vùng sản xuất nông nghiệp và NTTS bền vững. Báo cáo tổng kết KHCN đề tài cấp Bộ, 2010.

11. Thông, B.X. Đề xuất hướng cảnh báo mực nước biển dâng dị thường trong điều kiện phát triển sóng lừng kết hợp mực nước triều kỳ triều cường tại các vùng ven biển Việt Nam, Trung tâm Khí tượng Thủy văn Biển 2007.

12. Viện KHKTTV\&MT. Tác động của nước biển dâng và các biện pháp thích ứng ở Việt Nam, Bộ Tài nguyên và Môi trường, 2008.

13. Bộ Tài nguyên và Môi trường. Kịch bản Biến đổi Khí hậu, nước biển dâng cho Việt Nam. Nhà xuất bản Tài nguyên - Môi trường và Bản đồ Việt Nam, Hà Nội, 2012.

14. Bộ Tài nguyên và Môi trường. Kịch bản Biến đổi khí hậu và nước biển dâng cho Việt Nam. Nhà xuất bản Tài nguyên - Môi trường và Bản đồ Việt Nam, 2016.

15. IPCC. Climate Change: The Scientific Basis. Contribution of Working Group I to the Fourth Assessment Report of the Intergovernmental Panel on Climate Change, Cambridge University Press, Cambridge, United Kingdom and New York, NY, USA. 2007.

16. IPCC Fifth Assessment Report: Climate Change 2013 - The Physical Science Basis. Cambridge University Press, Cambridge, UK, 2013, pp. 1535.

17. IPCC. The Physical Science Basis. Contribution of Working Group I to the Fourth Assessment Report of the Intergovernmental Panel on Climate Change, 2007.

18. IPCC. The Physical Science Basis. Contribution of Working Group I to the Fifth Assessment Report of the Intergovernmental Panel on Climate Change, 2013.

19. IPCC. Managing the Risks of Extreme Events and Disasters to Advance Climate Change Adaptation, A Special Report of Working Groups I and II of the Intergovernmental Panel on Climate Change, Cambridge University Press, 2012.

20. Kaergaard, K.; Fredsoe, J. Numerical modeling of shoreline undulations part 1: Constant wave climate. Coast. Eng. 2013, 75, 64-76.

21. DHI - Water and Environment. Mike 11 - a Modeling System for Rivers and Channels, DHI Water and Environment, 2003.

22. NAM Reference Manual. DHI Water and Environment, Denmark, MIKE11 Introduction and tutoral; DHI Water \& Environment, Denmark. MIKE11 User Manual, 2014.

23. www.tnmtkhanhhoa.gov.vn/

24. www.dostkhanhhoa.gov.vn/

\title{
Water quality in Cai Nha Trang River basin before and after having salt prevention dam
}

\author{
Phu Huynh" ${ }^{*}$, Ngoc Thao Nguyen Ly ${ }^{1}$, Dong Dang Van², Dung Vu Huu ${ }^{3}$ \\ ${ }^{1}$ Ho Chi Minh City University of Technology, HUTECH; h.phu@ hutech.edu.vn; \\ nln.thao@hutech.edu.vn \\ ${ }^{2}$ DongVinh Co., Ltd; sales@dovitech.com.vn \\ ${ }^{3}$ Dung Vu Huu; vuhuudung93@gmail.com
}




\begin{abstract}
Nha Trang Cai River is one of the three major rivers of Khanh Hoa province, this river plays a very important role in providing fresh water for people's livelihood and socio-economic development. Research, using MIKE model with MIKE NAM module to calculate runoff due to rain, as input condition for MIKE 11 module, simulate saline intrusion and water quality in main city Nha Trang, Ninh Hoa town, Dien Khanh town, etc. When there is no dam, in upstream parameters such as BOD $5: 8.5 \mathrm{mg} / \mathrm{l}$, Total N 1.62-5.22 $\mathrm{mg} / \mathrm{l}$, these parameters also increase over time in dry season. Salinity at high tide is up to $31.55 \%$. When the dam was built, BOD 5 decreased from $8.5 \mathrm{mg} / \mathrm{l}$ to $4.13 \mathrm{mg} / \mathrm{l}$, salinity < 4\%. This paper presents the results of applying the Mike 11 model set to simulate the water quality of Cai Nha Trang River before and after the saline prevention dam.
\end{abstract}

Keywords: Cai Nha Trang River; Dam to prevent salinity; Salinity intrusion; Water quality. 